\title{
Sphincter of Oddi
}

National Cancer Institute

\section{Source}

National Cancer Institute. Sphincter of Oddi. NCI Thesaurus. Code C13065.

The muscle fibres around the opening of the common bile duct (ductus choledochus) into the duodenum at the papilla of Vater. 